\title{
Arthropod biodiversity associated to European sheep production systems
}

\author{
Rocío Rosa García ${ }^{\mathrm{a}, *}$, Tanja Peric ${ }^{\mathrm{b}}$, Vasco Cadavez ${ }^{\mathrm{c}}$, Andreas Geß ${ }^{\mathrm{d}}$, Joaquim Orlando Lima \\ Cerqueira $^{\mathrm{e}}$, Úrsula Gonzales-Barrón ${ }^{\mathrm{c}}$, Mario Baratta ${ }^{\mathrm{f}}$ \\ ${ }^{a}$ Servicio Regional de Investigación y Desarrollo Agroalimentario (SERIDA), 33300, Villaviciosa, Asturias, Spain \\ ${ }^{\mathrm{b}}$ Univerza v Novi Gorici, Vipavska 13, SI-5000, Nova Gorica, Slovenia \\ ${ }^{\mathrm{c}}$ Centro de Investigação de Montanha (CIMO), Escola superior Agrária, Instituto Politécnico de Bragança, Campus de Santa Apolonia, 5300-253, Bragança, Portugal \\ d Abteilung Ganzheitliche Bilanzierung (GaBi). Universität Stuttgart, Wankelstr. 5, 70563, Stuttgart, Germany \\ ${ }^{\mathrm{e}}$ Escola Superior Agrária do Instituto Politécnico de Viana do Castelo, 4990-706, Ponte de Lima, Portugal \\ ${ }^{\mathrm{f}}$ Dipartimento di Scienze Veterinarie, Università degli Studi di Torino, Largo Paolo Braccini 2, 10095, Grugliasco, Italy
}

\section{A R T I C L E I N F O}

\section{Keywords:}

Biodiversity

Sheep

Arthropods

Pollinators

Vegetation

Grazing

Ecosystem services

\begin{abstract}
A B S T R A C T
The rural territories linked to European sheep systems still cover wide areas and provide multiple ecosystems services although the current situation of the associated biodiversity is not fully understood. In this study the foliage arthropods (including pollinators), the vegetation cover and height, the number of flowers and plant species richness were evaluated in 9 sheep grazed lands from 5 EU countries with different livestock management strategies and dominant vegetation. The total abundance of arthropods, the abundance of Diptera and Heteroptera, sward height and plant species richness were higher in more extensive than in more intensively managed farms. The total abundance and the abundance of most of the orders were highest in mountain areas (MP) and lowest in improved pastures (IMP) whereas the total arthropod richness showed no differences and the richness of pollinators was lower in IMP than in MP ( $p<0.01)$ and semi-natural pastures $(\mathrm{SN}, \mathrm{p}<0.01)$. The grass cover was higher in IMP than in the rest of the areas whereas forb cover was higher in SN than in IMP (p $<0.01)$. The plant species richness peaked in MP whereas the number of flowers showed no significant differences. Sward height correlated positively with forb cover, plant species richness, the richness of the whole arthropod community, the abundance of several orders like Araneae, Diptera or Homoptera, as well as with the richness of the pollinator community. The community composition of the total arthropod fauna $(\mathrm{p}<0.01)$ and the pollinators in particular $(\mathrm{p}<0.05)$ differed between management strategies and more diverse groups were linked to the areas under more extensive management. Both communities (total and pollinators) also differed in composition between the types of vegetation $(\mathrm{p}<0.01)$ and less diverse assemblages with low abundant taxa were associated to IMP and SN whereas more diverse groups were linked to MP and grassland-forest (WP) in both cases. A better understanding of the flora-fauna dynamics in sheep grazed pasturelands is essential for the proper conservation of the biodiversity and other ecosystem services, as well as for the maintenance of sustainable sheep systems relying on the natural resources.
\end{abstract}

\section{Introduction}

Environmental protection is essential to support the global resilience required to face the future uncertainties (climate change, biodiversity loss, etc.), and it has become a greater priority within the European Community due to its role in the provision of strategic ecosystem services such as food, storage of soil carbon or biodiversity (De Groot et al., 2002; Cardinale et al., 2012). Such protection includes the agricultural territories where drastic changes in land use and land cover (e.g. expansion of forests, reductions in hay meadows and alpine pastures, etc.) threatens the future provision of services, starting with the biodiversity, as a result of simplification, loss, fragmentation, etc. of habitats and landscapes (Kruess and Tscharntke, 1994; IEEP and Alterra, 2010; Schirpke et al., 2020).

The drastic changes in agricultural systems in the EU are very frequently linked to those in the livestock production systems, and of small ruminants in particular (González Díaz et al., 2018). As a result of complex socio-economic and structural difficulties, the sheep sector has

\footnotetext{
* Corresponding author.

E-mail address: rocior@serida.org (R. Rosa García).
} 
become one of the most vulnerable livestock sectors in Europe (Belanche et al., 2021), although it contributes to many of the United Nations Sustainable Development Goals (Sargison, 2020) and operates in wide European areas, including protected ones with endangered plant and animal species, unique traditional landscapes and products, etc. (González Díaz et al., 2018, 2019).

A large part of abundance and diversity of the organisms living in sheep grazed habitats belongs to the arthropod communities, and they are directly and indirectly involved in the provision of crucial ecosystem services, from the recycling of the organic matter in the soil to the pollination of a large part of plant species (Longcore, 2003). The arthropod community contains excellent bioindicators to assess habitat quality and measure habitat differences (e.g., Niemelä et al., 1993; Longcore, 2003) due to their high sensitivity to environmental changes (Schowalter et al., 2003). The community composition is influenced by the characteristics of the habitat (including the vegetation structure and plant species composition in the sward) which in turn can be influenced by the grazing regime and/or the local conditions (Kleijn et al., 2001; Steffan-Dewenter et al., 2002, 2006; Rosa García et al., 2013; Rosa García and Fraser, 2019). The EU sheep systems are highly diverse in management strategies, socioeconomic and environmental characteristics. Our knowledge on the biodiversity associated to the varied sheep grazed areas is still limited and few studies performed a simultaneous evaluation of the situation in different EU territories. However, the efforts to value the potential of sheep systems to deliver key ecosystem services, including the conservation of the biodiversity, need to incorporate a deeper understanding of their multiple roles in the highly diverse European rural areas. Such efforts will also help to define the strategies which may promote a sustainable use of the natural resources, product valorisation and differentiation as well as the conservation of more resilient territories and rural communities.

In this study we examined the differences in arthropod foliage community (abundance, diversity and community composition) between sheep grazed territories across Europe which differ in the livestock management strategies and the types of dominant vegetation. We analysed the fauna-flora relationships and the influence of relevant plant parameters on fauna community composition.

\section{Materials and methods}

A total of 9 sheep-grazed study sites were selected to cover a wide variety of environmental conditions present in EU sheep systems (Table 1). The management systems were grouped in more extensive ones when sheep spent most of the grazing season outdoors and received no supplementation; and more intensive ones, with higher number of animals/ha and when additional food was provided and grazing periods were limited. Vegetation was not cut when the sheep were not grazing. More details on livestock management and sites characteristics can be found in Gonzales-Barron et al. (2021).

Fauna and flora data collection was carried out in 4-6 areas in each site during the maximum flowering period in 2018 to detect the majority of arthropod groups, and especially the pollinator community. The area was considered the statistical unit in all analyses.

The foliage arthropods were sampled with sweep nets as a rapid, inexpensive, and easily standardized protocol which has been successfully used to monitor their presence and responses to different management strategies, including sheep grazing (Rosa García and Miñarro, 2014; Rosa García and Fraser, 2019). The arthropods were sampled along six random linear transects ( $25 \mathrm{~m}$ long each one) per area and 25 sweeps were performed in each transect. The individuals collected from the 6 transects were pooled for each area. Arthropods were identified to Order level, and numerically dominant groups like the Orders Araneae, Hemiptera, Orthroptera and Coleoptera, were identified to family level. The use of families is considered a valid surrogate to measure invertebrate biodiversity and compare community composition (New, 1998; Oliver and Beattie, 1996; Patterson et al., 2019). Finally, the group of arthropods potentially involved in pollination (Roubik, 1995; Rosa García and Miñarro, 2014) in each farm was also identified. The percentage cover of the main vegetation components (forbs, grasses, bare ground, shrubs, etc.) and the number of flowers were recorded in 10 random quadrats $(50 \mathrm{~cm}$ side) per area. Additionally, 100 random counts of sward height were performed with a sward stick in each area. The data of each plant variable was averaged for each area for further analyses.

To quantify differences in the arthropod abundance and diversity between management strategies and the dominant vegetation available to sheep, the Analysis of Variance (Anova) was conducted with IBM SPSS Statistics version 23.0. The data was log transformed when necessary to meet assumptions of normality and homocedasticity. For any significant differences $(P \leq 0.05)$ post hoc Bonferroni tests for pairwise comparisons were used. Pearson correlations were performed to assess the relationships between fauna and flora variables.

Multivariate Redundancy analysis (RDA) in the CANOCO for Windows software package, v. 4.5 (ter Braak and Šmilhauer, 2002) was used to evaluate the differences in arthropod community composition between management strategies and types of vegetation. The adequacy of this method was confirmed by a preliminary detrended correspondence analyses (DCA) which yielded short axes lengths of $<$ 3SD (Lepš and Šmilauer, 2003). Another RDA was used to calculate the variability in arthropod species abundance accounted for by selected plant variables (plant height, the number of flowers, plant species richness and the percentage cover of grasses and forbs) coded as quantitative variables. All analyses were performed on log transformed arthropod data, using inter-species correlations, dividing by standard deviation and centering by species. The statistical significance was evaluated by the F-ratio based on the trace and 499 Monte Carlo permutations with unconstrained permutations under a reduced model. Ordinations were plotted using CanoDraw version 4.0 (CANOCO; ter Braak and Šmilhauer, 2002) to visualize the results.

Table 1

Description of the farms in each country indicating the type of management, bioregion, dominant vegetation (Vegetation) and the number of samples/site (N).

\begin{tabular}{|c|c|c|c|c|c|c|}
\hline Country & Site & Code & Management & Bioregion & Vegetation & $\mathrm{N}$ \\
\hline Italy & Saretto & IT & extensive & Alpine & MP & 5 \\
\hline Germany & Münsingen & GE & extensive & Continental & WP & 4 \\
\hline Spain & Grado SS & ES1 & extensive & Atlantic & IMP & 6 \\
\hline Portugal & Arufe & PT1 & extensive & Mediterranean & WP & 4 \\
\hline Portugal & Bragança & PT2 & intensive & Mediterranean & IS & 4 \\
\hline Portugal & Gemieira & PT3 & extensive & Atlantic & SN & 4 \\
\hline Portugal & Refoios & PT4 & intensive & Atlantic & IS & 4 \\
\hline
\end{tabular}

Dominant vegetation (Veg): grassland-forests (WP); improved pastures (IMP), mountain pastures (MP), improved pastures + indoor supplementation (IS), seminatural grasslands (SN). 


\section{Results and discussion}

A total of 51,474 arthropods were recorded in the study sites and they belonging to 3 classes, 17 orders and 93 different taxa, including 13 families of spiders (Order Araneae), 36 families of beetles (Order Coleoptera), 13 families of true bug (SubOrder Heteroptera), 8 families of leafhoppers, cicadas, etc. (SubO. Homoptera) and 3 families of grassphoppers and katydids (Order Orthoptera). The most abundant groups were flies (Order Diptera, $34.4 \%$ of all individuals), SubOrder Homoptera (14.9\%), springtails (Order Symphypleona, $14.9 \%$ ), Order Coleoptera (11.7\%) and the mega-diverse group which includes ants, bees, wasps, etc. (Order Hymenoptera, $9.7 \%$ ). The group of pollinators contained 21,089 arthropods from 40 different taxa (Table 2).

The univariate analyses revealed that the total abundance of arthropods and the abundance of the Orders Diptera and Heteroptera were higher under more extensive than under more intensive management ( $\mathrm{p}$ $<0.01$ ) whereas no differences were detected for the abundance of pollinators, the catches of the rest of orders, the global arthropod richness and the richness of pollinators in particular (Table 3 ). Regarding the responses of vegetation parameters, sward height $(\mathrm{p}<0.01)$ and plant species richness $(\mathrm{p}<0.001)$ were higher in more extensive than in more intensive sites while the rest of plant parameters were similar between management strategies. Inconsistent responses of the arthropod groups to varied stocking rates and site-specific responses for several taxa were detected in an experiment carried out in several European countries although, generally reaching the highest abundance and diversity in the less intensively grazed sites (Wallis De Vries et al., 2007). Previous studies have associated the higher global arthropod records in more extensively used areas with the presence of a wider variety of resources (food, shelter, microclimatic conditions, etc.) there than in more intensively and homogeneous ones (Dennis, 2003; Jeanneret et al., 2003; Wallis De Vries et al., 2007).

Fauna and flora variables showed variable responses attending to the dominant vegetation in each area (Table 3 ). The total arthropod abundance was highest in Alpine mountain pastures (MP) and lowest in the farms where sheep had limited access to pasturelands (IS, $p<0.01$ ), whereas no differences were detected for the abundance of pollinators. The catches of flies (Order Diptera) also differed between vegetation types $(\mathrm{p}<0.001)$ and they were highest in MP compared to grassland and forest systems (WP, $\mathrm{p}<0.001$ ), improved pastures (IMP, $\mathrm{p}<0.05$ ), IS ( $p<0.001)$ and semi-natural pastures (SN, $\mathrm{p}<0.01$ ). The second highest records of flies occurred in IMP and they were significantly higher there than in WP $(\mathrm{p}<0.01)$ and IS ( $<<0.001)$. The abundances of true bugs (Order Heteroptera) were highest in WP followed by MP and lowest in SN and IS (Table 3). The post-hoc analyses confirmed higher abundances in WP than in IMP, IS and SN $(\mathrm{p}<0.001)$, and in MP than in IS $(\mathrm{p}<0.001)$ and SN $(\mathrm{p}<0.01)$. The Order Hymenoptera was more abundant in MP ( $<<0.001)$ than in WP, IS and SN, and also $(\mathrm{p}<0.05)$ than in IMP. The butterflies (Order Lepidoptera) also differed between types of vegetation $(\mathrm{p}<0.001)$ and the highest abundances occurred in MP and WP and the lowest in SN and IMP (Table 3). MP held higher records of this order than IMP ( $\mathrm{p}<0.001$ ), IS and SN ( $p<0.01$ for both comparisons), and WP showed higher abundances than IMP ( $\mathrm{p}<0.001)$, IS $(p<0.05)$ and $S N(p<0.01)$. The records of grasshoppers were again highest in MP and WP and lowest in SN and IMP (Table 3), with significant lower catches in SN than in WP and MP ( $p<0.05)$. The Order Symphypleona showed higher abundances in SN than in MP $(\mathrm{p}<0.05$, Table 3). This order proliferates in humid environments and certain species can reach high numbers in grass dominated pastures where they can become a pest (Rosa García and Fraser, 2019).

The global arthropod richness did not differ between the types of vegetation whereas the richness of pollinators varied $(p<0.001)$ and it was lower in IMP (Table 3$)$ than in MP and SN ( $<<0.01)$, and it also tended to be lower than in WP $(P=0.060)$.

Regarding the responses of plant variables, the percentage of cover of both grasses $(p<0.001)$ and forbs $(p<0.01)$ varied between types of vegetation (Table 3 ). The grass cover was highest in IMP ( $p<0.001$ for the comparison with MP and SN and $\mathrm{p}<0.01$ for the comparison with WP and IS). By contrast, forb cover was highest in SN and lowest in IMP ( $\mathrm{p}<0.01$ ). The plant species richness peaked in MP and it was lowest in IS and SN (Table 3). The pairwise comparisons showed significant lower records in IS than in WP and IMP (both $\mathrm{p}<0.001)$ and MP $(\mathrm{p}<0.01)$, and also lower richness in SN than in IMP $(\mathrm{p}<0.001)$, and in WP than in MP ( $p<0.05)$. The number of flowers did not differ significantly between the dominant types of vegetation.

The characteristics of the vegetation structure and plant community composition in the sward can influence the arthropod community (Kleijn et al., 2001; Steffan-Dewenter et al., 2002; Tscharntke et al., 2005; Steffan-Dewenter et al., 2006) so fauna-flora relationships were explored. The sward height showed a positive correlation a higher percentage cover of forbs $\left(\mathrm{R}^{2}=0.31, \mathrm{p}<0.05\right)$, plant species richness $\left(\mathrm{R}^{2}=0.44, \mathrm{p}<0.01\right)$, total arthropod richness $\left(\mathrm{R}^{2}=0.38, \mathrm{p}<0.05\right)$, the richness of pollinators $\left(\mathrm{R}^{2}=0.42, \mathrm{p}<0.01\right)$ as well as with the abundance of certain orders like Araneae $\left(\mathrm{R}^{2}=0.31, \mathrm{p}<0.05\right)$, Diptera $\left(\mathrm{R}^{2}=\right.$ $0.33, \mathrm{p}<0.05)$ and Homoptera $\left(\mathrm{R}^{2}=0.43, \mathrm{p}<0.01\right)$. A positive relationship between sward height and the abundance of invertebrates is consistent with previous studies which relate it with a higher degree of heterogeneity in the territory which provides a wider variety of resources for more complex communities (e.g., Dennis et al., 2008; Morris and Plant, 1983). For example, the presence of areas with higher sward height can benefit groups which require food, shelter or architecture for the orb webs like spiders and their herbivorous preys (Dennis et al., 2015).

The percentage cover of grasses in this study correlated negatively with the percentage cover of forbs $\left(R^{2}=-0.82, p<0.001\right)$, the richness of pollinators $\left(\mathrm{R}^{2}=-0.42, \mathrm{p}<0.01\right)$ and the abundance of Orthoptera $\left(\mathrm{R}^{2}=0.39, \mathrm{p}<0.05\right)$. The inverse relationship in the percentage covers of grasses and forbs has been detected in previous studies (Rosa García and Fraser, 2019) and the negative relationship between the percentage cover of grasses and the abundance of pollinators could be related to the higher presence of wind-pollinated species and more reduced availability of pollen or nectar although grasses can include host plants to numerous groups (e.g. butterflies) and can provide nesting and overwintering sites. The negative correlation with Orthoptera is likely related to the higher abundance of taxa from the SubOrden Ensifera in the samples and which include less herbivorous species which are more common in less grassy areas.

The percentage cover of forbs was positively correlated to the sward height $\left(\mathrm{R}^{2}=0.31, \mathrm{p}<0.05\right)$ and the presence of higher number of flowers $\left(\mathrm{R}^{2}=0.38, \mathrm{p}<0.05\right)$. In upland permanent grasslands Rosa García and Fraser (2019) detected more abundant and diverse arthropod communities in flower-rich and forb-dominated plots managed by hay cutting and by hay cutting with aftermath sheep grazing, although certain groups were more abundant in grazed only and grass-dominated plots.

In the present study the areas with higher plant species richness correlated positively the abundances of Diptera $\left(R^{2}=0.63, p<0.001\right)$ and Heteroptera $\left(\mathrm{R}^{2}=0.36, \mathrm{p}<0.05\right)$ and negatively with the abundance of Coleoptera $\left(\mathrm{R}^{2}=-0.42, \mathrm{p}<0.01\right)$ and Symplypleona $\left(\mathrm{R}^{2}=\right.$ $-0.38, p<0.05)$. The association of more complex communities to areas with higher plant diversity is already known (Ebeling et al., 2018) and the negative correlations with Coleoptera may be linked to the higher abundances of several families in certain locations whereas the Symphypleona has been previously recorded in more homogeneous and less diverse swards (Rosa García and Fraser, 2019). Finally, the richness of pollinators $\left(\mathrm{R}^{2}=0.49, \mathrm{p}<0.001\right)$, and the abundance of Coleoptera $\left(\mathrm{R}^{2}\right.$ $=0.38, \mathrm{p}<0.05)$, and it also tended to correlate as well with the abundance of pollinators $\left(\mathrm{R}^{2}=0.29, \mathrm{p}=0.069\right)$. A positive relationship between the diversity of pollinators and the abundance of flowers is already known from other territories (e.g. Carvell, 2002; Sjodin, 2007) and it has also been associated to areas with higher percentage cover of forbs in upland permanent pastures (Rosa García and Fraser, 2019). 
Table 2

Abundance (number of individuals) of each arthropod group recorded in the different sheep grazed sites in 2018.

\begin{tabular}{|c|c|c|c|c|c|c|c|c|c|c|c|}
\hline Таха & $\mathrm{Abb}$ & ES1 & ES2 & GE & IT & $\begin{array}{l}\text { SITE } \\
\text { PT1 }\end{array}$ & PT2 & PT3 & PT4 & SL & Total \\
\hline \multicolumn{12}{|l|}{ Class Arachnida } \\
\hline \multicolumn{12}{|l|}{ Order Araneae } \\
\hline Family Anyphaenidae & Any & & 1 & & & & & & & & 1 \\
\hline Family Araneidae & Ara & 14 & 33 & 4 & 6 & 19 & 5 & 10 & 5 & 16 & 112 \\
\hline Family Dictynidae & Dic & & & & & & 1 & 9 & 1 & & 11 \\
\hline Family Eutichuridae & Eut & & 2 & & & & 2 & 1 & & & 5 \\
\hline Family Gnaphosidae & Gna & 1 & & & & 13 & & 1 & 1 & & 16 \\
\hline Family Linyphiidae & Lin & 45 & 57 & 7 & 9 & 25 & 4 & 12 & 2 & 22 & 183 \\
\hline Family Lycosidae & Lyc & 8 & 7 & & & 2 & & & 1 & 1 & 19 \\
\hline Family Oxyopidae & Oxy & 1 & 1 & & & 28 & 8 & 8 & 3 & & 49 \\
\hline Family Philodromidae & Phi & & 1 & & 1 & 11 & 4 & 2 & 1 & 4 & 24 \\
\hline Family Salticidae & Salt & 2 & 2 & & 1 & 16 & 5 & 1 & 4 & 2 & 33 \\
\hline Family Tetragnathidae & Tetra & 1 & 3 & & & & & & & 1 & 5 \\
\hline Family Theridiidae & Ther & 8 & 12 & 2 & 7 & 6 & & 19 & 4 & 19 & 77 \\
\hline Family Thomisidae & Tho & 66 & 37 & 38 & 14 & 25 & 146 & 87 & 16 & 12 & 441 \\
\hline \multicolumn{12}{|l|}{ Orden Ixodida } \\
\hline Family Ixodidae & Ixo & & 1 & 1 & & & & & & 3 & 5 \\
\hline \multicolumn{12}{|l|}{ Orden Opiliones } \\
\hline Family Phalangiidae & Pha & & & & & & & 1 & & 13 & 14 \\
\hline \multicolumn{12}{|l|}{ Class Collembola } \\
\hline Order Entomobryomorpha & Ent & 80 & 102 & & 1 & 56 & 17 & & & 8 & 264 \\
\hline Order Symphypleona * & Sym & 616 & 1392 & 11 & 203 & 2032 & 241 & 2266 & 808 & 110 & 7679 \\
\hline \multicolumn{12}{|l|}{ Class Insecta } \\
\hline Order Coleoptera & & & & & & & & & & & \\
\hline Family Alleculidae * & All & & & & 1 & & 1 & & & & 2 \\
\hline Family Anobiidae & Ano & & & & 1 & 1 & & & & & 2 \\
\hline Family Anthicidae * & Anti & 1 & & & 168 & 1 & & 1 & & & 171 \\
\hline Family Bostrichidae & Bost & & 1 & & & 1 & & & & 1 & 3 \\
\hline Family Bruchidae * & Bruc & & 1 & 1 & & 2478 & 521 & 440 & 99 & & 3540 \\
\hline Family Buprestidae * & Bup & & & & & & 2 & 1 & & 4 & 7 \\
\hline Family Cantharidae * & Can & 1 & 10 & 3 & 20 & 2 & & 1 & & & 37 \\
\hline Family Carabidae & Carab & 1 & 2 & & & 4 & & & & & 7 \\
\hline Family Cerambycidae * & Cer & & & 5 & 3 & & & & & 1 & 9 \\
\hline Family Chrysomelidae * & Chrym & 39 & 55 & 21 & 5 & 25 & 50 & 20 & 20 & 218 & 453 \\
\hline Family Clambidae & Clam & & & & & 1 & & & & & 1 \\
\hline Family Coccinellidae * & $\mathrm{Coc}$ & 10 & 9 & 5 & 2 & 2 & 39 & 3 & 15 & 1 & 86 \\
\hline Family Corylophidae & Cory & & & & 1 & & 1 & & & & 2 \\
\hline Family Curculionidae * & Cur & 42 & 92 & 18 & 14 & 225 & 65 & 36 & 15 & 46 & 553 \\
\hline Family Dascillidae & Dasc & & & 1 & 1 & & & & & & 2 \\
\hline Family Elateridae * & Ela & 33 & 48 & 9 & 8 & 1 & & 7 & 3 & 1 & 110 \\
\hline Family Helophoridae & Hel & 1 & & & & & & & & & 1 \\
\hline Family Histeridae & Hist & 1 & & & & & & & & & 1 \\
\hline Family Hydrophilidae & Hyd & 9 & 4 & & & & & & & & 13 \\
\hline Family Kateridae & Kat & 2 & 13 & & & & & & & & 15 \\
\hline Family Lathridiidae * & Lat & 5 & 3 & & & & 6 & 9 & 4 & & 27 \\
\hline Family Leiodidae & Lei & & & & & 2 & & & & & 2 \\
\hline Family Meloidae * & Melo & & & & 2 & 1 & & & & & 3 \\
\hline Family Melyridae * & Mely & & & & 32 & 355 & 22 & 5 & 26 & 9 & 449 \\
\hline Family Monotomidae & Mon & & 1 & & & & & & & & 1 \\
\hline Family Mordellidae * & Mor & & & & & & & & 1 & 14 & 15 \\
\hline Family Nitidulidae * & Nit & 1 & & 5 & & 7 & 2 & 8 & & 7 & 30 \\
\hline Family Oedemeridae * & Oed & & & & & & 2 & & & 22 & 24 \\
\hline Family Omalisidae & Oma & & & 1 & & & & & & & 1 \\
\hline Family Phalacridae * & Phal & 1 & & & & 77 & 76 & 33 & 4 & & 191 \\
\hline Family Ptiliidae & Pti & 2 & 1 & & 4 & & & & & 2 & 9 \\
\hline Family Salpingidae & Salp & & & & 1 & & & & & & 1 \\
\hline Family Scarabaeidae * & Sca & 37 & 29 & 4 & 4 & 7 & 1 & 10 & & 1 & 93 \\
\hline Family Scraptiidae * & Scra & & & & 3 & & 13 & & & & 16 \\
\hline Family Silvanidae & Sil & & & & 1 & & & & & & 1 \\
\hline Family Staphylinidae * & Sta & 31 & 41 & 3 & 14 & 6 & 1 & 9 & 6 & 8 & 119 \\
\hline Order Dermaptera & & & & & & & & & & & \\
\hline Family Forficulidae * & Forf & & & & & & & 2 & & & 2 \\
\hline Order Diptera & & & & & & & & & & & \\
\hline Diptera & Dip & 1715 & 2147 & 837 & 4291 & 366 & 693 & 880 & 419 & 2766 & 14,114 \\
\hline Family Sepsidae & Sep & 353 & 457 & 44 & 835 & & 8 & 21 & 7 & 1563 & 3288 \\
\hline Family Syrphidae * & Syr & 3 & 1 & 137 & 66 & & 41 & 9 & 11 & 27 & 295 \\
\hline Order Hemiptera & & & & & & & & & & & \\
\hline Suborder Heteroptera & & & & & & & & & & & \\
\hline Family Alydidae & Aly & 1 & & & & & 2 & & & & 3 \\
\hline Family Anthocoridae * & Antho & & & & 1 & 1 & & 2 & & & 4 \\
\hline Family Berytidae & Bery & & & & & 12 & & & & 1 & 13 \\
\hline Family Coreidae * & Core & & 1 & 9 & 2 & 1 & & 3 & & 1 & 17 \\
\hline Family Cydnidae & Cyd & 2 & 2 & & 1 & 1 & 2 & 2 & & 2 & 12 \\
\hline
\end{tabular}




\begin{tabular}{|c|c|c|c|c|c|c|c|c|c|c|c|}
\hline Taxa & Abb & ES1 & ES2 & GE & IT & $\begin{array}{l}\text { SITE } \\
\text { PT1 }\end{array}$ & PT2 & PT3 & PT4 & SL & Total \\
\hline Family Lygaeidae * & Lyg & 2 & 2 & & 10 & 3 & & 7 & 3 & 4 & 31 \\
\hline Family Miridae * & Mir & 103 & 198 & 477 & 444 & 1301 & 8 & 8 & 33 & 276 & 2848 \\
\hline Family Nabidae & $\mathrm{Nab}$ & 1 & 1 & 2 & & & & & & 10 & 14 \\
\hline Family Pentatomidae * & Pen & & 3 & 4 & 2 & 7 & 16 & 5 & 2 & 1 & 40 \\
\hline Family Rhopalidae & Rho & & & 1 & 2 & 2 & 8 & 1 & & 3 & 17 \\
\hline Family Scutelleridae * & Scu & & & 4 & & & 6 & 1 & & & 11 \\
\hline Family Scydnidae & Scy & & 1 & & & & & & & & 1 \\
\hline Family Tingidae & Tin & & 2 & 1 & & & 3 & 1 & & 1 & 8 \\
\hline \multicolumn{12}{|l|}{ Suborder Homoptera } \\
\hline Family Aphididae & Aphi & 1516 & 1841 & 313 & 557 & 99 & 118 & 327 & 1028 & 107 & 5906 \\
\hline Family Aphrophoridae & Aphr & & & 1 & & & 10 & 7 & 14 & & 32 \\
\hline Family Cercopidae & Cerc & & & 2 & 1 & & & & & & 3 \\
\hline Family Cicadellidae & $\mathrm{Cic}$ & 209 & 212 & 92 & 213 & 331 & 160 & 47 & 32 & 251 & 1547 \\
\hline Family Cixiidae & Cix & 1 & & & & 1 & & & & & 2 \\
\hline Family Delphacidae & Del & 40 & 65 & 11 & 12 & & 1 & 1 & & 2 & 132 \\
\hline Family Issidae & Iss & & & & & & 1 & & & & 1 \\
\hline Family Psyllidae & Psy & & 1 & 7 & 6 & 1 & 2 & 3 & 10 & 41 & 71 \\
\hline \multicolumn{12}{|l|}{ Order Hymenoptera } \\
\hline Family Apidae * & Apid & & & 1 & 4 & 1 & & 14 & & 1 & 21 \\
\hline Family Formicidae * & Form & 29 & 39 & 43 & 91 & 15 & 174 & 19 & 42 & 523 & 975 \\
\hline Hymenoptera & Hym & 617 & 734 & 47 & 710 & 278 & 161 & 144 & 194 & 938 & 3823 \\
\hline Wild bee * & Wil & 11 & 14 & 1 & 11 & 17 & 22 & 35 & 7 & 41 & 159 \\
\hline \multicolumn{12}{|l|}{ Order Lepidoptera } \\
\hline Heterocera * & Het & 2 & 5 & 25 & 28 & 11 & 15 & 1 & 1 & 29 & 117 \\
\hline Lepidoptera * & Lep & 2 & 1 & 22 & 35 & 14 & 6 & 1 & 1 & 7 & 89 \\
\hline \multicolumn{12}{|l|}{ Order Mecoptera } \\
\hline Family Panorpidae * & Pan & & & & & & & 2 & & 1 & 3 \\
\hline \multicolumn{12}{|l|}{ Order Neuroptera } \\
\hline Family Chrysopidae * & Chryp & & & 2 & 14 & & 1 & & & & 17 \\
\hline Family Hemerobiidae * & Hem & & & & & & & & & 1 & 1 \\
\hline \multicolumn{12}{|l|}{ Order Odonata } \\
\hline Family Coenagrionidae & Coe & & & & & & 2 & & & & 2 \\
\hline \multicolumn{12}{|l|}{ Order Orthroptera } \\
\hline Family Acrididae * & Acr & 3 & 13 & 38 & 69 & 51 & 90 & & 8 & 124 & 396 \\
\hline Family Tetrigidae & Tetr & & 5 & & & & & & & 1 & 6 \\
\hline Family Tettigoniidae * & Tett & 19 & 28 & 10 & 8 & 19 & 9 & 6 & 6 & 133 & 238 \\
\hline Order Pscoptera & Psc & 1 & & & & & & & & 1 & 2 \\
\hline Order Thysanoptera * & Thy & 590 & 129 & 105 & 514 & 354 & 400 & 71 & 32 & 83 & 2278 \\
\hline
\end{tabular}

Abb: Abbreviations for species shown in the ordination diagrams (RDA analyses). The groups considered potential pollinators are identified with an asterisk (*). For site abbreviations see Table 1.

Table 3

Mean flora and fauna variables according to the management strategies (Int, Ext) and types of dominant vegetation (WP, IMP, MP, IS, SN). Percentage cover of grasses (\% Grass cover) and forbs (\% Forb cover), number of plant species (No species) and number of flowers ( $\mathrm{N}^{\circ}$ flowers). Total arthropod richness (Total richness), richness of pollinators, total arthropod abundance (Total abundance), abundance of pollinators as well as abundance of the main orders of arthropods.

\begin{tabular}{|c|c|c|c|c|c|c|c|c|c|c|}
\hline \multirow[b]{2}{*}{ Response variable } & \multicolumn{4}{|c|}{ Management } & \multicolumn{5}{|c|}{ Type of vegetation } & \multirow[b]{2}{*}{ Sig. } \\
\hline & Int & Ext & SEM & Sig. & WP & IMP & MP & IS & SN & \\
\hline Vegetation height & 12.70 & 21.59 & 1.52 & $* *$ & 16.58 & 21.25 & 23.58 & 12.70 & 28.13 & $\mathrm{~ns}$ \\
\hline$\%$ Grass cover & 47.31 & 47.90 & 3.94 & ns & 45.45 & 74.89 & 23.88 & 47.31 & 25.88 & $* * *$ \\
\hline$\%$ Forbs cover & 43.69 & 43.53 & 3.00 & ns & 40.69 & 31.56 & 51.71 & 43.69 & 66.75 & $* *$ \\
\hline $\mathrm{N}^{\circ}$ Species & 2.41 & 8.14 & 0.60 & $* * *$ & 6.71 & 9.25 & 10.23 & 2.41 & 2.98 & $* * *$ \\
\hline $\mathrm{N}^{\circ}$ flowers & 23.23 & 16.50 & 3.08 & ns & 25.31 & 7.76 & 12.74 & 23.23 & 33.55 & ns \\
\hline Total richness & 28.63 & 31.61 & 0.88 & ns & 31.25 & 29.83 & 33.11 & 28.63 & 34.25 & $\mathrm{~ns}$ \\
\hline Richness pollinators & 16.38 & 17.09 & 0.67 & ns & 18.13 & 13.42 & 19.33 & 16.38 & 21.00 & $* * *$ \\
\hline Total abundance & 760.38 & 1375.48 & 128.07 & $* *$ & 1336.25 & 1178.50 & 1771 & 760.375 & 1155.00 & $*$ \\
\hline Abundance pollinators & 372.13 & 548.85 & 102.86 & ns & 997.13 & 302.42 & 385.67 & 372.13 & 758.75 & ns \\
\hline Order Araneae & 26.63 & 23.12 & 3.45 & ns & 24.50 & 25.17 & 12.78 & 26.63 & 37.50 & ns \\
\hline Order Coleoptera & 124.38 & 151.58 & 47.02 & ns & 409.00 & 43.92 & 68.89 & 124.38 & 145.75 & ns \\
\hline Order Diptera & 147.38 & 500.55 & 70.56 & $* *$ & 173.00 & 389.67 & 1060.89 & 147.38 & 227.50 & $* * *$ \\
\hline Order Heteroptera & 10.38 & 88.97 & 21.25 & $* *$ & 228.25 & 26.58 & 84.56 & 10.38 & 7.50 & $* * *$ \\
\hline Order Homoptera & 172.00 & 191.45 & 30.95 & ns & 107.25 & 323.75 & 132.22 & 172.00 & 96.25 & ns \\
\hline Order Hymenoptera & 75.00 & 132.67 & 16.58 & ns & 50.38 & 120.33 & 257.67 & 75.00 & 53.00 & $* * *$ \\
\hline Order Lepidoptera & 2.88 & 5.55 & 0.93 & ns & 9.00 & 0.83 & 11.00 & 2.88 & 0.50 & $* * *$ \\
\hline Order Orthoptera & 14.13 & 15.97 & 3.29 & ns & 14.75 & 5.67 & 37.22 & 14.13 & 1.50 & $* *$ \\
\hline Order Symphypleona & 131.13 & 200.91 & 45.91 & ns & 255.38 & 167.33 & 34.78 & 131.13 & 566.50 & $* *$ \\
\hline Order Thysanoptera & 54.00 & 55.94 & 12.77 & ns & 57.38 & 59.92 & 66.33 & 54.00 & 17.75 & ns \\
\hline
\end{tabular}

Int: Intensive; Ext: extensive; Type of vegetation: grassland-forests (WP); improved pastures (IMP), mountain pastures (MP), improved pastures + supplementation (IS), seminatural grasslands (SN). SEM: Standard error of means; sig.: Significance level: *P $<0.05$; ** $\mathrm{P}<0.01$; *** $<<0.001$; ns: not significant (P $>0.05$ ). 
Multivariate RDA analyses allowed a more detailed analysis of the responses of the total arthropod community composition and the pollinator community to the different sets of environmental variables. Both the total community $(\mathrm{p}<0.01$ ) and the assemblages of pollinators ( $\mathrm{p}<$ 0.05 ) differed between management strategies (Table 4). In both cases the number of taxa linked to more intensive strategies was lower than the ones favoured by more extensive management, whereas a diverse group did not favour one strategy in particular (Fig. 1). The groups preferring more intensive management include families from Orthoptera like Acrididae which are more frequently associated to more open and grassier areas whereas other Orthoptera like Tettigonidae (including bush crickets) or true bugs (Heteroptera) from the family Miridae are more common in areas under more extensive management and higher vegetation cover. Other arthropods more linked to more extensive systems included Lepidoptera which depend on the presence of specific plant species and floral resources. The detrimental effects of intensive grazing on butterfly and grasshopper diversity has already been confirmed in previous studies (Kruess and Tscharntke, 2002; Wallis De Vries et al., 2007) and the reductions of Miridae populations under more intensive grazing management has been linked to the reduction of their preferred oviposition sites and the accumulations of litter which provide diurnal refuges for nymphs (O'Neill et al., 2008).

The global arthropod community composition and the community of pollinators (Fig. 2) also differed between types of vegetation ( $\mathrm{p}<0.01$, Table 5). Less diverse communities with low abundant taxa were associated to IMP and SN whereas more diverse assemblages associated to MP and WP in both cases. The taxa linked to IMP and SN was restricted to families less frequent in the foliage layer like earwigs (Forficulidae) or scorpionflies (Panorpidae) whereas the groups more associated to MP and WP included well known pollinators like hoverflies (Syrphidae), butterflies (Lepidoptera) or soft-wing flower beetles (Melyridae). When the plant variables were included as environmental variables in the RDA analyses, the resulting model was significant for the whole arthropod community and for the community of pollinators in particular $(\mathrm{p}<0.01$, Table 6). Both analyses revealed that the areas with higher percentage of grasses favoured a limited number of taxa whereas the areas with higher presence of flowers, percentage cover of forbs or higher sward height associated to more diverse arthropod assemblages. The availability of taller swards may benefit groups which act as passive pollinators like bushcrikets (Tettigoniidae) or true bugs from the family Miridae (Fig. 3) whereas the areas with higher presence of forbs or flowers favour taxa which depend more on nectar or pollen like wild bees, bees (Apidae) or flower chafers (Scarabaeidae).

Table 4

Results of RDA analyses to test the influence of the management strategy (extensive versus intensive) on the total arthropod foliage community composition/the community of pollinators in the EU sheep grazed areas during 2018. Results of non-standardized tests are provided.

\begin{tabular}{lllll}
\hline Axis & 1 & 2 & 3 & 4 \\
\hline Eigenvalues & $0.086 /$ & $0.230 /$ & $0.153 /$ & $0.113 /$ \\
& 0.074 & 0.264 & 0.213 & 0.102 \\
Species-environ corr & $0.657 /$ & & & \\
& 0.647 & & & \\
Cumulative \% variance: & & & & $58.2 /$ \\
Of species data & $8.6 / 7.4$ & $31.6 /$ & $46.9 /$ & 65.3 \\
Of sp-envir rela & $100.0 /$ & 33.8 & 55.1 & \\
Monte Carlo test : & 100.0 & & & \\
Sig. of all canonical axes: & F-ratio: $3.669 / 3.119$ & P-value: $0.0040 / 0.0140$ \\
$\quad$ Trace: $0.086 / 0.074$ & & & & \\
\hline
\end{tabular}

Species-environ corr: Species-environment correlation. sp-envir rela: speciesenvironment relation. Sig. Significance.

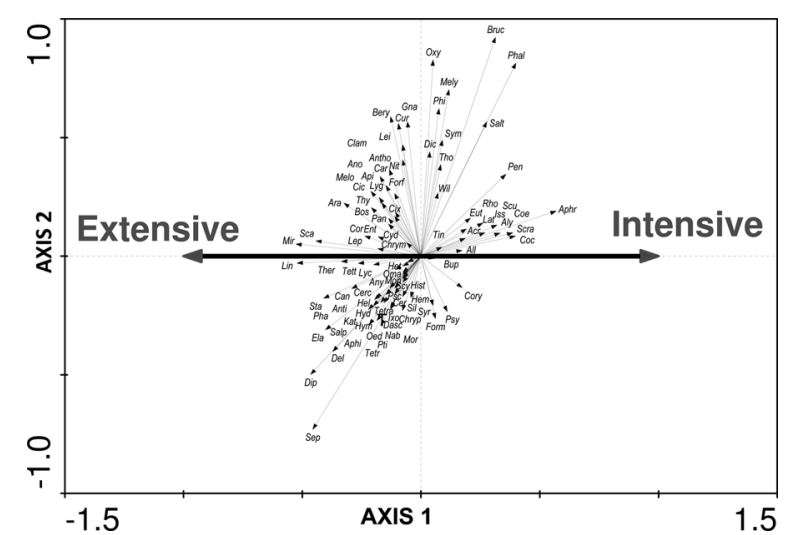

Fig. 1. Biplot of RDA analysis which explored the relationships between the total arthropod foliage community and the management strategies (extensive and intensive represented with dotted arrows) in the sheep grazed sites. See Table 2 for arthropod fauna abbreviations.

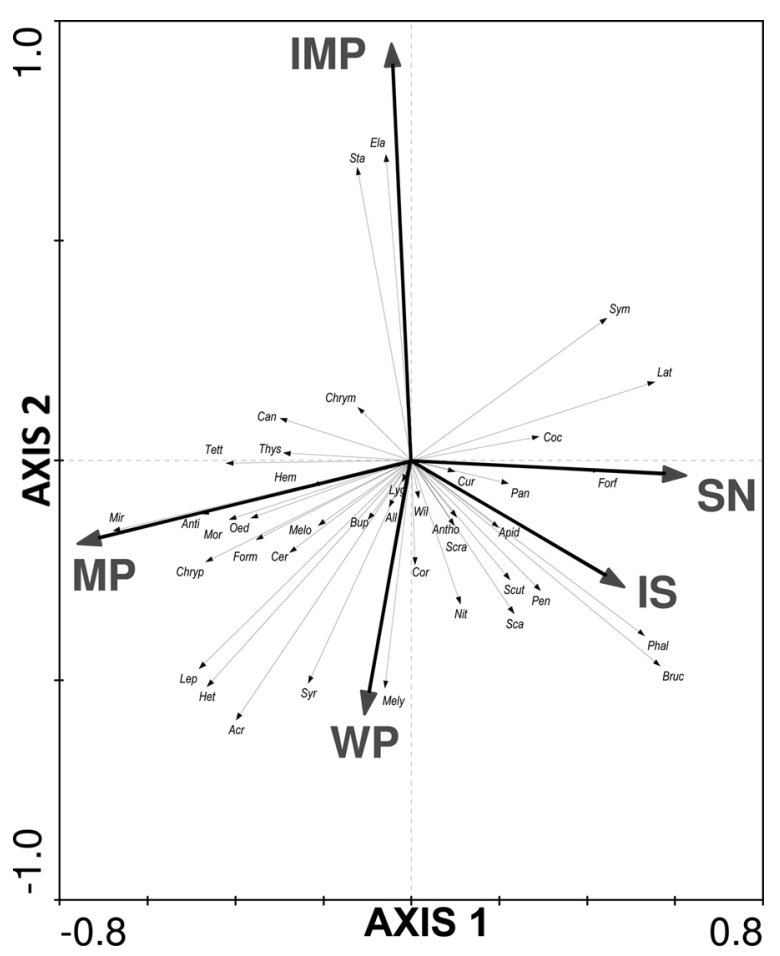

Fig. 2. Biplot of RDA analysis which explored the relationships between the community of pollinators and the types different types of dominant vegetation (represented with dotted arrows): grassland-forests (WP); improved pastures (IMP), mountain pastures (MP), improved pastures + indoor supplementation (IS), semi-natural grasslands (SN). See Table 2 for arthropod fauna abbreviations.

\section{Conclusions}

The conservation of extensively managed pasturelands can play a relevant role to ensure the provision of multiple ecosystem services including the conservation of the flora and fauna biodiversity which are highly interdependent. Numerous investigations confirm that local diversity is greatest at intermediate grazing intensities, i.e. when disturbance is neither absent nor too frequent (Kok et al., 2020). A targeted management of livestock grazing behaviour and diet selection, as well as grazing pressure and the grazing periods, have to be taken into consideration to sustain animal production and maintain heterogeneous pasturelands suitable for diverse plant and animal communities (Rosa 
Table 5

Results of RDA analyses to test the responses of the total arthropod foliage community composition/the community of pollinators to the different types of vegetation. The analyses are based on data collected during 2018. Results of non-standardized tests are provided.

\begin{tabular}{lllll}
\hline Axis & 1 & 2 & 3 & 4 \\
\hline Eigenvalues & $0.208 /$ & $0.126 /$ & $0.050 /$ & $0.020 /$ \\
& 0.181 & 0.139 & 0.046 & 0.021 \\
Species-environ corr & $0.908 /$ & $0.933 /$ & $0.868 /$ & $0.763 /$ \\
& 0.870 & 0.832 & 0.792 & 0.751 \\
Cumulative \% variance: & & & & \\
Of species data & $20.8 / 18.1$ & $33.4 / 32.0$ & $38.4 / 36.6$ & $40.4 / 38.7$ \\
Of sp-envir rela & $51.5 / 46.7$ & $82.7 / 82.7$ & $95.0 / 94.7$ & $100.0 /$ \\
& & & & 100.0 \\
Test of significance of: & & & & \\
First Canonical axis: & F-ratio: $9.455 / 7.952$ & P-value: $0.0020 / 0.0020$ \\
All canonical axes: Trace: & F-ratio: $6.094 / 5.684$ & P-value: $0.0020 / 0.0020$ \\
$\quad$ 0.404/0.387 & & & & \\
\hline
\end{tabular}

Species-environ corr: Species-environment correlation. sp-envir rela: speciesenvironment relation.

Table 6

Results of RDA analyses to test the responses of the total arthropod foliage community composition/the community of pollinators to selected plant variables: sward height, percentage cover of forbs and grasses, plant species richness and number of flowers. The analyses are based on data collected during 2018. Results of non-standardized tests are provided.

\begin{tabular}{lllll}
\hline Axis & 1 & 2 & 3 & 4 \\
\hline Eigenvalues & $0.213 /$ & $0.103 /$ & $0.048 /$ & $0.029 /$ \\
& 0.227 & 0.116 & 0.038 & 0.024 \\
Species-envir corr & $0.902 /$ & $0.840 /$ & $0.768 /$ & $0.726 /$ \\
& 0.906 & 0.764 & 0.654 & 0.768 \\
Cumulative \% variance: & & & & \\
Of species data & $21.3 / 22.7$ & $31.6 / 34.3$ & $36.3 / 38.1$ & $39.3 / 40.5$ \\
Of sp-envir rela & $52.5 / 54.6$ & $78.0 / 82.5$ & $89.7 / 91.6$ & $96.9 / 97.4$ \\
Test of significance of: & & & & \\
First Canonical axis: & F-ratio: $9.452 / 10.255$ & P-value: $0.0020 / 0.0020$ \\
All canonical axes: Trace: & F-ratio: 4.766/4.972 & P-value: $0.0020 / 0.0020$ \\
$\quad$ 0.405/ 0.415 & & & & \\
\hline
\end{tabular}

Species-envir corr: Species-environment correlation. sp-envir rela: speciesenvironment relation.

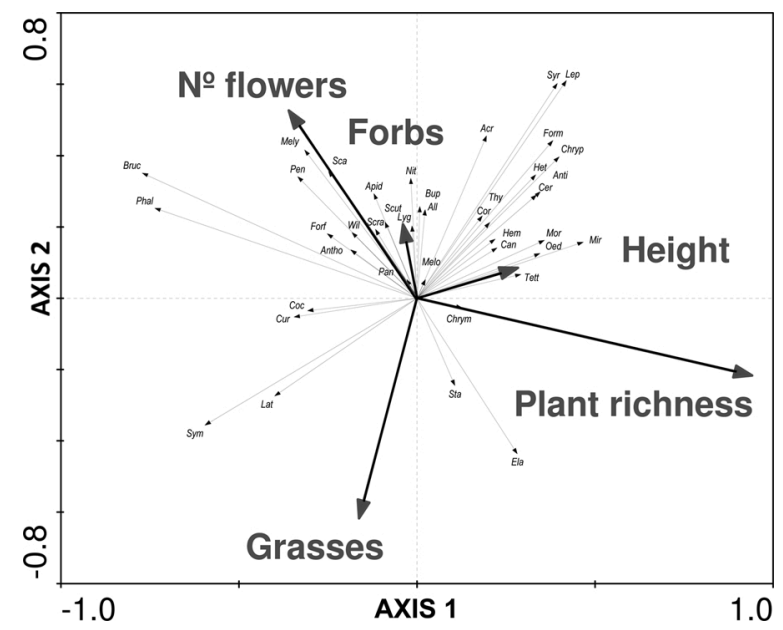

Fig. 3. Ordination diagram resulting from RDA analysis which explored the relationships between the community of pollinators and selected plant variables (represented with dotted arrows): Number of flowers (No flowers), percentage cover of forbs (Forbs), percentage cover of grasses (Grasses), mean sward height (Height) and number of plant species (Plant richness). See Table 2 for arthropod fauna abbreviations.
García et al., 2013).

This study evidenced the relevance of mountain areas which hold a remarkable biodiversity, frequently composed of endemic species (Essl et al., 2009), which can be potentially affected by the global warming (Gobiet et al., 2014) and the changes in land use (Müller et al., 2017), so the conservation of these areas should be actively guaranteed. In other territories with poorer plant and animal communities the recovery of the local biodiversity can be achieved by a combination of strategies which could include prescribed sheep grazing (alone or in mixed herds with other livestock species) and the inclusion of forbs and legumes in the swards as they are key resources for the local fauna, improve soil health and provide nutritive and healthy feed for animal production. A diverse plant community can favour arthropod niche diversification and the coexistence of species with a diversity of functional traits (Hooper et al., 2005; Rzanny and Voigt, 2012) which can improve ecosystem service provision (Albrecht et al., 2012; Manning et al., 2015).

This study confirmed that pollinators would benefit from areas with taller swards and higher presence of flowers. Extensive sheep systems which preserve areas with diverse swards heights and favour the presence of diverse flowering plants would benefit pollinators but also other important groups like spiders and their herbivorous preys (e.g. members of Homoptera), flies, etc. Furthermore, the conservation of diverse fauna and flora communities in sheep grazed areas can have positive benefits at broader spatial scale as reported by Klein et al. (2003) or Kremen et al. (2004) who considered that a spillover of pollinators from grasslands to the surrounding habitats could enhance pollination at the landscape scale.

\section{CRediT authorship contribution statement}

Rocío Rosa García: Conceptualization, Formal analysis, Funding acquisition, Investigation, Methodology, Project administration, Resources, Software, Visualization, Writing - original draft, Writing - review \& editing. Tanja Peric: Funding acquisition, Project administration, Resources, Visualization, Writing - review \& editing. Vasco Cadavez: Funding acquisition, Project administration, Resources, Visualization, Writing - review \& editing. Andreas Geß: Funding acquisition, Project administration, Resources, Visualization, Writing - review \& editing. Joaquim Orlando Lima Cerqueira: Investigation, Methodology, Supervision, Validation, Visualization. Úrsula Gonzales-Barrón: Funding acquisition, Investigation, Methodology, Project administration, Resources, Software, Visualization, Writing review \& editing. Mario Baratta: Funding acquisition, Project administration, Resources, Visualization, Writing - review \& editing.

\section{Declaration of Competing Interest}

The authors have no competing interests to declare. No financial and personal relationships with other people or organizations have detected that could inappropriately influence (bias) their work.

\section{Acknowledgements}

This work funded as a part of the ERA-Net Cofund SusAn (grant number 696231). SERIDA authors are grateful to the Spanish Research State Agency (Agencia Estatal de Investigación) for the financial support (PCIN2017-111).

\section{References}

Albrecht, M., Schmid, B., Hautier, Muller, C.B., 2012. Diverse pollinator communities enhance plant reproductive success. Proc. Biol. Sci. 279, 4845-4852. https://doi. org/10.1098/rspb.2012.1621.

Belanche, A., Martñin-Collado, D., Rose, G., Yáñez-Ruiz, D.R., 2021. A multi-stakeholder participatory study identifies the priorities for the sustainability of the small ruminants farming sector in Europe. Animal 15 (2), 100131. https://doi.org/ 10.1016/j.animal.2020.100131. 
Cardinale, B., Duffy, J.E., Gonzalez, A., Hopper, D.U., Perrings, C., Venail, P., Narwani, A., Made, G.M., Tilman, D., Wardle, D.A., Kinzig, A.P., Daily, G.C. Loreau, M., Grace, J.B., Larigaudarie, A., Srivastava, D.S., Naeem, S., 2012. Biodiversity loss and its impact on humanity. Nature 486, 59-67. https://doi.org/ 10.1038/nature11148.

Carvell, C., 2002. Habitat use and conservation of bumblebees grassland management regimes (Bombus spp.) under different. Biol. Conserv. 103, 33-49. https://doi.org/ 10.1016/S0006-3207(01)00114-00118.

De Groot, R., Wilson, M., Boumans, R., 2002. A typology for the classification description and valuation of ecosystem functions, goods and services. Ecol. Econ. 41 (3), 393-408. https://doi.org/10.1016/S0921-8009(02)00089-7.

Dennis, P., 2003. Sensitivity of upland arthropod diversity to livestock grazing, vegetation structure and landform. Food Agric. Environm. 1 (2), 301-307. https:// doi.org/10.1016/S1389-1723(03)80082-80088.

Dennis, P., Skartveit, J., McCracken, D.I., Pakeman, R.J., Beaton, K., Kunaver, A., Evans, D.M., 2008. The effects of livestock grazing on foliar arthropods associated with bird diet in upland grasslands of Scotland. J. Appl. Ecol. 45, 279-287. https:// doi.org/10.1111/j.1365-2664.2007.01378.x.

Dennis, P., Skartveit, J., Kunavera, A., McCrackenc, D.I., 2015. The response of spider (Araneae) assemblages to structural heterogeneity and prey abundance in submontane vegetation modified by conservation grazing. Global Ecol. Conserv. 3, 715-728. https://doi.org/10.1016/j.gecco.2015.03.007.

Ebeling, A., Hines, J., Hertzog, L.R., Lange, M., Meyer, S.T., Simons, N.K., Weisser, W.W. 2018. Plant diversity effects on arthropods and arthropod-dependent ecosystem functions in a biodiversity experiment. Basic Appl. Ecol. 26, 50-63. https://doi.org/ 10.1016/j.baae.2017.09.014.

Essl, F., Staudinger, M., Stöhr, O., Schratt-Ehrendorfer, L., Rabitsch, W., Niklfeld, H., 2009. Distribution patterns, range size and niche breadth of Austrian endemic plants. Biol. Conserv. 142, 2547-2558. https://doi.org/10.1016/j.biocon.2009.05.027.

Gobiet, A., Kotlarski, S., Beniston, M., Heinrich, G., Rajczak, J., Stoffel, M., 2014. 21st century climate change in the European Alps-a review. Sci. Total Environ. 493, 1138-1151. https://doi.org/10.1016/j.scitotenv.2013.07.050.

Gonzales-Barron, U., Coelho-Fernandes, S., Santos-Rodrigues, G., Choupina, A., Bermúdez Piedra, R., Osoro, K., Celaya, R., García, R.R., Peric, T., Del Bianco, S., Piasentier, E., Chiesa, F., Brugiapaglia, A., Battaglini, L., Baratta, M., Bodas, R., Lorenzo, J.M., Cadavez, V.A.P., 2021. Microbial deterioration of lamb meat from European local breeds as affected by its intrinsic properties. Small Rumin. Res. 195, 106298 https://doi.org/10.1016/j.smallrumres.2020.106298.

González Díaz, J.A., Celaya, R., Fraser, M.D., Osoro, K., Ferreira, L.M.M., Fernández García, F., González Díaz, B., Rosa García, R., 2018. Agroforestry systems in northern Spain. The role of land management and socioeconomy in the dynamics of landscapes. In: Chander Degar, J., Prasad Tewari, V. (Eds.), Agroforestry: Anecdotal to Modern Science. Springer, Singapore, pp. 189-215.

González Díaz, J.A., Celaya, R., Fernández García, F., Osoro, K., Rosa García, R., 2019. Dynamics of rural landscapes in marginal areas of northern Spain: past, present, and future. Land Degrad. Dev. 30 (2), 141-150. https://doi.org/10.1002/ldr.3201.

Hooper, D.U., Chapin, F.S., Ewel, J.J., Hector, A., Inchausti, P., Lavorel, S., Lawton, J.H., Lodge, D.M., Loreau, M., Naeem, S., Schmid, B., Setälä, H., Symstad, A.J. Vandermeer, J., Wardle, D., 2005. Effects of biodiversity on ecosystem functioning: a consensus of current knowledge. Ecol. Monogr. 75, 3-35. https://doi.org/10.1890/ 04-0922.

IEEP and Alterra, 2010. Reflecting environmental land use needs into EU policy: preserving and enhancing the environmental benefits of "land services": soil sealing, biodiversity corridors, intensification / marginalisation of land use and permanent grassland. Final Report to the European Commission, DG Environment on Contract ENV.B.1/ETU/2008/0030. Institute for European Environmental Policy / Alterra Wageningen UR. https://ec.europa.eu/environment/agriculture/pdf/Land_services \%20-\%20Final\%20Report.pdf.

Jeanneret, P., Schüpbach, B., Pfiffner, L., Walter, T., 2003. Arthropod reaction to landscape and habitat features in agricultural landscapes. Landscape Ecol. 18, 253-263. https://doi.org/10.1023/A:1024496712579.

Kleijn, D., Berende, F., Smit, R., Gilissen, N., 2001. Agri-environment schemes do not effectively protect biodiversity in Dutch agricultural landscapes. Nature 413, 723-725. https://doi.org/10.1038/35099540.

Klein, A.M., Steffan-Dewenter, I., Tscharntke, T., 2003. Pollination of Coffea canephora in relation to local and regional agroforestry management. J. Appl. Ecol. 40, 837-845. https://doi.org/10.1046/j.1365-2664.2003.00847.x.

Kok, A., de OLde, E.M., de Boer, I.J.M., Ripoll-Bosch, R., 2020. European biodiversity assessment in livestock science: a review of research characteristics and indicators. Ecol. Indic. 112, 105902 https://doi.org/10.1016/j.ecolind.2019.105902.

Kremen, C., Williams, N.M., Bugg, R.L., Fay, J.P., Thorp, R.W., 2004. The area requirements of an ecosystem service: crop pollination by native bee communities in California. Ecol. Letters 7, 1109-1119. https://doi.org/10.1111/j.14610248.2004.00662.x.

Kruess, A., Tscharntke, T., 1994. Habitat fragmentation, species loss, and biological control. Science 264, 1581-1584. https://doi.org/10.1126/science.264.5165.1581.

Kruess, A., Tscharntke, T., 2002. Contrasting responses of plant and insect diversity to variation in grazing intensity. Biol. Conserv. 106, 293-302. https://doi.org/ 10.1016/S0006-3207(01)00255-5.
Lepš, J., Šmilauer, T., 2003. Multivariate Analysis of Ecological Data Using CANOCO. Cambridge University Press, Cambridge.

Longcore, T., 2003. Terrestrial arthropods as indicators of ecological restoration success in coastal sage scrub (California, U.S.A.). Restor. Ecol. 11, 397-409. https://doi.org/ 10.1046/j.1526-100X.2003.rec0221.x.

Manning, P., Gossner, M.M., Bossdorf, O., Allan, E., Zhang, Y., Prati, D., Blüthgen, N., Boch, S., Böhm, S., Börschig, C., Hölzel, N., Jung, K., Klaus, V.H., Klein, A.M., Kleinebecker, T., Krauss, J., Lange, M., Müller, J., Pašalić, E., Socher, S.A., Tschapka, M., Türke, M., Weiner, C., Werner, M., Gockel, S., Hemp, A., Renner, S.C., Wells, K., Buscot, F., Kalko, E.K.V., Linsenmair, K.E., Weisser, W.W., Fischer, M., 2015. Grassland management intensification weakens the associations among the diversities of multiple plant and animal taxa. Ecology 96, 1492-1501. https://doi. org/10.1890/14-1307.1.

Morris, M.G., Plant, R., 1983. Responses of grassland invertebrates to management by cutting. J. Appl. Ecol. 20, 157-177. https://doi.org/10.2307/2402730.

Müller, J., Berg, C., Détraz-Méroz, J., Fort, N., Lambelet-Haueter, C., Margreiter, V., Mondoni, A., Pagitz, K., Porro, F., Rossi, G., Schwager, P., Breman, E., 2017. The alpine seed conservation and research network - a new initiative to conserve valuable plant species in the European Alps. J. Sci. 73, 251-256. https://doi.org/ 10.1007/s11629-016-4313-4318.

New, T., 1998. Invertebrate Surveys for Conservation. Oxford University Press, Oxford.

Niemelä, J., Langor, D., Spence, J.R., 1993. Effects of clear-cut harvesting on boreal ground-beetle assemblages (Coleoptera: carabidae) in western Canada. Conserv. Biol. 7, 551-561. https://www.jstor.org/stable/2386683.

O'Neill, K.M., Blodgett, S., Olson, B.E., Miller, R.S., 2008. Impact of livestock grazing on abundance of Miridae and Reduviidae (Hemiptera) in crested wheatgrass pastures. J. Econ. Entomol. 101 (2), 309-313. https://doi.org/10.1603/0022-0493.

Oliver, I., Beattie, A.J., 1996. Invertebrate morphospecies as surrogates for species: a case study. Conserv. Biol. 10, 99-109. https://www.jstor.org/stable/2386948.

Patterson, E.S.P., Sanderson, R.A., Eyre, M.D., 2019. Soil tillage reduces arthropod biodiversity and has lag effects within organic and conventional crop rotations. J. Appl. Entomol. 143, 430-440. https://doi.org/10.1111/jen.12603.

Rosa García, R., Fraser, M.D., 2019. Impact of management on foliage-dwelling arthropods and dynamics within permanent pastures. Sci. Rep. 9, 11090. https://doi. org/10.1038/s41598-019-46800-w.

Rosa García, R., Miñarro, M., 2014. Role of floral resources in the conservation of pollinator communities in cider-apple orchards. Agric., Ecosyst. Environ. 183, 118-126. https://doi.org/10.1016/j.agee.2013.10.017.

Rosa García, R., Fraser, M.D., Celaya, R., Ferreira, L.M.M., García, U., Osoro, K., 2013. Grazing land management and biodiversity in the Atlantic European heathlands: a review. Agroforest. Syst. 87 (1), 19-43. https://doi.org/10.1007/s10457-012-95193.

Roubik, D.W., 1995. Pollination of Cultivated Plants in the Tropics. FAO Agricultural Services Bulletin No. 118. Food and Agriculture Organization of the United Nations (FAO), Rome.

Rzanny, M., Voigt, W., 2012. Complexity of multitrophic interactions in a grassland ecosystem depends on plant species diversity. J. Animal Ecol. 81, 614-627. https:// doi.org/10.1111/j.1365-2656.2012.01951.x.

Sargison, N.D., 2020. The critical importance of planned small ruminant livestock health and production in addressing global challenges surrounding food production and poverty alleviation. New Zeal. J. Vet. 68, 136-144. https://doi.org/10.1080/ 00480169.2020.1719373.

Schirpke, U., Tscholl, S., Tasser, E., 2020. Spatio-temporal changes in ecosystem service values: effects of land-use changes from past to future (1860-2100). J. Environ. Manag. 272, 111068 https://doi.org/10.1016/j.jenvman.2020.111068.

Schowalter, T.D., Zhang, Y.L., Rykken, J.J., 2003. Litter invertebrate responses to variable density thinning in western Washington forest. Ecol. Appl. 13, 1204-1211. https://doi.org/10.1046/j.1526-100X.2003.rec0221.x.

Sjodin, N.E., 2007. Pollinator behavioural responses to grazing intensity. Biodiv. Conserv. 16, 2103-2121. https://doi.org/10.1007/s10531-006-9103-0.

Steffan-Dewenter, I., Münzenberg, U., Bürger, C., Thies, C., Tscharntke, T., 2002. Scaledependent effects of landscape structure on three pollinator guilds. Ecology 83, 1421-1432. https://doi.org/10.2307/3071954.

Steffan-Dewenter, I., Klein, A.M., Alfert, T., Gaebele, V., Tscharntke, T., 2006. Bee diversity and plant-pollinator interactions in fragmented landscapes. In: Waser, N. M., Ollerton, J. (Eds.), Specialization and Generalization in Plant-Pollinator Interactions. Chicago Press, Chicago, pp. 387-408.

ter Braak, C.J.F., Šmilhauer, P., 2002. Canoco reference manual and user's Guide to Canoco for windows. Software for Canonical Community Ordination (Version 4.5). Microcomputer Power, Ithaca, NY, USA.

Tscharntke, T., Klein, A.M., Kruess, A., Steffan-Dewenter, I., Thies, C., 2005. Landscape perspectives on agricultural intensification and biodiversity ecosystem service management. Ecol. Letters 8, 857-874. https://doi.org/10.1111/j.14610248.2005.00782.x.

Wallis De Vries, M.F., Parkinson, A.E., Dulphy, J.P., Sayer, M., Diana, E., 2007. Effects of livestock breed and grazing intensity on biodiversity and production in grazing systems. 4. Effects on animal diversity. Grass Forage Sci. 62, 185-197. https://doi. org/10.1111/j.1365-2494.2007.00568.x. 